\title{
Normal laboratory values for differential white cell counts established by manual and automated cytochemical methods (Hemalog $\left.\mathrm{D}^{\mathrm{TM}}\right)^{1}$
}

\author{
A. SIMMONS, P. LEAVERTON, AND G. ELBERT
}

From the Department of Pathology, Hematology Section, University of Iowa Hospitals and Clinics, and the Department of Environmental Medicine and Statistics, University of Iowa, Iowa City, USA

SYNOPSIS The central 95 percentile estimates of the normal white cell types (as determined by a standard differential count) were calculated from 777 normal individuals. The results were divided into groups by age and sex and expressed both as percentages and as absolute numbers of cells.

A similar survey was made using the prototype of a new automated differential counting method (Hemalog-D ${ }^{\text {TM }}$ ).

The two sets of laboratory values showed no statistically significant differences regarding age or sex and were strikingly similar in most cell types with the exception of band and juvenile forms of granulocytes. As expected, the normal range using the manual technique was somewhat broader than that found with the automated method. In addition to being the first comparison of machine counts with visual differentials this study provides additional insight into the age distributions of normal cells.

Although the 'normal range' for differential white counts has been reported by many investigators, much disagreement is evident concerning both the percentage and the absolute numbers of cells constituting this range. Extreme normal limits for neutrophils have been reported as $33-75 \%$ and 47-79.5\% (Zacharski, Elueback, and Linman, 1971); lymphocytes as $12 \cdot 5-40 \cdot 0 \%$ and $15 \cdot 0-60 \%$ (Whitby and Britton, 1963) and 25-35\% (Fowler, 1945); monocytes as $\mathbf{0 - 9} \cdot \mathbf{0} \%$ (Osgood, Brownlee, Osgood, Ellis, and Cohen, 1939) and $2 \cdot 0-11 \%$ (Zacharski et al, 1971); eosinophils as $0-7.2 \%$ (Wintrobe, 1967) and 2-0.3\% (Sturgis and Bethell, 1943); and basophils as $\mathbf{0 - 2 . 0 \%}$ (Sandoz, 1952). Most observers have not reported a normal range for bands probably because of the controversial arbitrary classification problems defining cellular age, although Orfanakis, Ostlund, Bishop, and Athens (1970) have recently reported the range as between 200 and 2150 bands per cubic mm of blood and Miale (1967) as $5 \cdot 0-11 \cdot 0 \%$.

There is little documentation in the literature of

${ }^{1}$ A preproduction apparatus, TMTechnicon Corporation, Tarrytown, New York.

Received for publication 12 September 1973. normal ranges when determined as falling between the 2.5 and 97.5 percentiles of the sample distribution, the classic \pm 2 standard deviations being universally used. This approach, while easy to compute and generally accepted, is only correct if the biological data approximate a Gaussian distribution. If the data are skewed, then the acceptable central $95 \%$ group would not be the same as that defined from \pm 2 standard deviations. This is seen more easily when bands, monocytes, eosinophils, and basophil plots are examined, all of which exhibit a skewed distribution. Differences relative to either age or sex in white cell differentials are poorly documented and there is only limited agreement in differential counts expressed as absolute number of cells (Whitby and Britton, 1963; Orfanakis et al, 1970). Furthermore, data are not available using the Hemalog-D. This apparatus is a multisegmental analyzer that determines white cell differential counts in a continuous flow-through system by selectively staining and sizing 10000 leucocytes in a 60-second interval. Unlike standard morphological methods, the analyzer separates the various leucocytes in EDTA-anticoagulated whole blood by cytochemical stains: peroxidase for neutrophils and eosinophils; lipase for monocytes; and toluidine blue. 


\begin{tabular}{|c|c|c|c|c|c|c|c|c|c|}
\hline & Class & Percentlles & Bands & Segmented & $\begin{array}{l}\text { Eosin- } \\
\text { ophils }\end{array}$ & $\begin{array}{l}\text { Baso- } \\
\text { phils }\end{array}$ & $\begin{array}{l}\text { Lymph- } \\
\text { ocytes }\end{array}$ & Monocytes & $n$ \\
\hline In percentages & $\begin{array}{l}\text { Total } \\
\text { Male } \\
\text { Female }\end{array}$ & $\begin{array}{l}2 \cdot 5 \\
50 \\
97 \cdot 5 \\
2 \cdot 5 \\
50 \\
97 \cdot 5 \\
2 \cdot 5 \\
50 \\
97 \cdot 5\end{array}$ & $\begin{array}{l}0 \\
1 \\
5 \\
0 \\
1 \\
6 \\
0 \\
1 \\
6\end{array}$ & $\begin{array}{l}42 \\
61 \\
81 \\
41 \\
59 \\
79 \\
41 \\
59 \\
80\end{array}$ & $\begin{array}{l}0 \\
2 \\
7 \\
0 \\
1 \\
7 \\
0 \\
1 \\
6\end{array}$ & $\begin{array}{l}0 \\
0 \\
1 \\
0 \\
0 \\
1 \\
0 \\
0 \\
1\end{array}$ & $\begin{array}{r}10 \\
29 \\
47 \\
9 \\
29 \\
49 \\
9 \\
28 \\
47\end{array}$ & $\begin{array}{r}2 \\
5 \\
10 \\
0 \\
3 \\
11 \\
0 \\
3 \\
10\end{array}$ & $\begin{array}{l}777 \\
404 \\
373\end{array}$ \\
\hline $\begin{array}{l}\text { In absolute } \\
\text { numbers/cmm }\end{array}$ & Total & $\begin{array}{l}2 \cdot 5 \\
50 \\
97 \cdot 5\end{array}$ & $\begin{array}{r}0 \\
66 \\
406\end{array}$ & $\begin{array}{l}1750 \\
3740 \\
6360\end{array}$ & $\begin{array}{r}0 \\
196 \\
475\end{array}$ & $\begin{array}{r}0 \\
0 \\
136\end{array}$ & $\begin{array}{r}590 \\
1720 \\
3200\end{array}$ & $\begin{array}{r}0 \\
184 \\
710\end{array}$ & 777 \\
\hline
\end{tabular}

Table I Percentile estimates of differential white counts in normal individuals by manual counts

for basophils. Lymphocytes are estimated by cell sizing.

This study estimates the 2.5 and 97.5 percentile ranges of differential manual and automated white counts in a healthy group of individuals. The percentile estimates are divided into age classes and into male and female classifications.

\section{Methods}

Blood was obtained from 777 healthy individuals ranging in age from 5 years to 74 years. Volunteers were obtained from blood donors, hospital staff, the medical staff and students, and from a group of healthy local school children. The smears were made from EDTA anticoagulated venous samples and stained using the Hema-Tek TMr slide stainer. One 100 cell differential count was determined by the routine laboratory staff and the results were subjected to analysis.

Tus Ames Co. Elkhart, Indiana.
Six hundred and sixty-eight of the 777 blood samples tested manually were evaluated by the Hemalog-DTM apparatus and compared with the manual normal ranges.

\section{Results}

The results of the analysis of the differential manual white counts of 777 non-hospitalized normal individuals are shown in table $I$. The analysis separates the $2 \cdot 5,50$, and 97.5 percentile estimates for both male and female and expresses them in percentages and in absolute numbers of cells per cubic millimetre of blood.

Table II designates the percentage breakdown using the same percentile estimates for age groups $10-19,20-29,30-39,40-49$, and $50-59$ years.

The results of the cytochemical differentiation of 668 of the normal group of individuals using the Hemalog-DTM are shown in table III. The $2 \cdot 5,50$, and 97.5 percentile estimates of each white cell type are given by both percentage and absolute methods.

\begin{tabular}{|c|c|c|c|c|c|c|c|c|c|}
\hline Age & Percentiles & Bands & Segmented & $\begin{array}{l}\text { Eosin- } \\
\text { ophils }\end{array}$ & $\begin{array}{l}\text { Baso- } \\
\text { phils }\end{array}$ & $\begin{array}{l}\text { Lymph- } \\
\text { ocytes }\end{array}$ & $\begin{array}{l}\text { Mono- } \\
\text { cytes }\end{array}$ & $n$ & $\begin{array}{c}\text { Percentage } \\
\text { of Total" }\end{array}$ \\
\hline $10-19$ & $\begin{array}{l}2 \cdot 5 \\
50 \\
97 \cdot 5\end{array}$ & $\begin{array}{l}0 \\
2 \cdot 0 \\
6 \cdot 0\end{array}$ & $\begin{array}{l}39 \\
59 \\
79\end{array}$ & $\begin{array}{l}0 \\
1 \\
8\end{array}$ & $\begin{array}{l}0 \\
0 \\
2\end{array}$ & $\begin{array}{l}14 \\
27 \\
54\end{array}$ & $\begin{array}{r}0 \\
4 \\
12\end{array}$ & 126 & 15 \\
\hline $20-29$ & $\begin{array}{l}2 \cdot 5 \\
50 \\
97 \cdot 5\end{array}$ & $\begin{array}{l}0 \\
1.0 \\
6.0\end{array}$ & $\begin{array}{l}40 \\
60 \\
81\end{array}$ & $\begin{array}{l}0 \\
1 \\
7\end{array}$ & $\begin{array}{l}\mathbf{0} \\
\mathbf{0} \\
\mathbf{2}\end{array}$ & $\begin{array}{r}9 \\
29 \\
45\end{array}$ & $\begin{array}{r}0 \\
3 \\
10\end{array}$ & 342 & 44 \\
\hline $30-39$ & $\begin{array}{l}2 \cdot 5 \\
50 \\
97 \cdot 5\end{array}$ & $\begin{array}{l}0 \\
0 \\
5-0\end{array}$ & $\begin{array}{l}40 \\
60 \\
79\end{array}$ & $\begin{array}{l}0 \\
1 \\
7\end{array}$ & $\begin{array}{l}0 \\
0 \\
2\end{array}$ & $\begin{array}{l}12 \\
33 \\
49\end{array}$ & $\begin{array}{c}0 \\
2 \cdot 5 \\
10\end{array}$ & 156 & 20 \\
\hline $40-49$ & $\begin{array}{l}2 \cdot 5 \\
50 \\
97 \cdot 5\end{array}$ & $\begin{array}{l}0 \\
0 \\
5 \cdot 5\end{array}$ & $\begin{array}{l}40 \\
61 \\
80\end{array}$ & $\begin{array}{l}0 \\
1 \\
4\end{array}$ & $\begin{array}{l}0 \\
0 \\
2\end{array}$ & $\begin{array}{r}9 \\
28 \\
45\end{array}$ & $\begin{array}{c}0 \\
2 \\
10 \cdot 5\end{array}$ & 69 & 9 \\
\hline $50-59$ & $\begin{array}{l}2 \cdot 5 \\
50 \\
97 \cdot 5\end{array}$ & $\begin{array}{l}0 \\
0 \\
4 \cdot 0\end{array}$ & $\begin{array}{l}39 \\
59 \\
77\end{array}$ & $\begin{array}{l}0 \\
1 \\
8\end{array}$ & $\begin{array}{l}0 \\
0 \\
2\end{array}$ & $\begin{array}{l}10 \\
30 \\
48\end{array}$ & $\begin{array}{c}0 \\
4 \cdot 5 \\
10 \cdot 0\end{array}$ & 58 & 8 \\
\hline
\end{tabular}

Table II Breakdown of age differences of the results of table I

'All results expressed as percentages.

*Twenty-four blood specimens additionally obtained from individuals aged between 5-9 and 60-74 years. 


\begin{tabular}{|c|c|c|c|c|c|c|c|c|c|c|}
\hline & Class & Percentiles & Juvenile & Segmented & $\begin{array}{l}\text { Eosin- } \\
\text { ophils }\end{array}$ & $\begin{array}{l}\text { Baso- } \\
\text { phils }\end{array}$ & $\begin{array}{l}\text { Lymph- } \\
\text { ocytes }\end{array}$ & $\begin{array}{l}\text { Mono- } \\
\text { cytes }\end{array}$ & $\begin{array}{l}\text { Unclassi- } \\
\text { fied }\end{array}$ & $n$ \\
\hline In percentages & $\begin{array}{l}\text { Total } \\
\text { Male } \\
\text { Female }\end{array}$ & $\begin{array}{l}2 \cdot 5 \\
50 \\
97 \cdot 5 \\
2 \cdot 5 \\
50 \\
97 \cdot 5 \\
2 \cdot 5 \\
50 \\
97 \cdot 5\end{array}$ & $\begin{array}{r}1 \cdot 35 \\
5 \cdot 85 \\
13 \cdot 26 \\
1 \cdot 30 \\
6 \cdot 10 \\
13 \cdot 35 \\
1 \cdot 41 \\
5 \cdot 71 \\
13.10\end{array}$ & $\begin{array}{l}47 \cdot 56 \\
62 \cdot 65 \\
74 \cdot 57 \\
46 \cdot 51 \\
61 \cdot 87 \\
75 \cdot 04 \\
47 \cdot 71 \\
62 \cdot 98 \\
74 \cdot 34\end{array}$ & $\begin{array}{l}0.30 \\
1.60 \\
5.54 \\
0.31 \\
1.65 \\
5.60 \\
0.30 \\
1.57 \\
5.44\end{array}$ & $\begin{array}{l}0.10 \\
0.35 \\
1.47 \\
0.12 \\
0.47 \\
1.54 \\
0.10 \\
0.31 \\
1.44\end{array}$ & $\begin{array}{c}1586 \\
25 \cdot 60 \\
38 \cdot 55 \\
14 \cdot 61 \\
26 \cdot 23 \\
39 \cdot 18 \\
16 \cdot 90 \\
23 \cdot 88 \\
37 \cdot 82\end{array}$ & $\begin{array}{r}1 \cdot 40 \\
7 \cdot 25 \\
11.61 \\
1.41 \\
7 \cdot 76 \\
11 \cdot 59 \\
1.40 \\
7 \cdot 00 \\
11.50\end{array}$ & $\begin{array}{l}-3.21 \\
+1.45 \\
+10.13 \\
-3.50 \\
+0.97 \\
+9.91 \\
-3.04 \\
+1.79 \\
+11.43\end{array}$ & 668 \\
\hline $\begin{array}{l}\text { In absolute } \\
\text { numbers } / \mathrm{cmm}\end{array}$ & Total & $\begin{array}{l}2 \cdot 5 \\
50 \\
97 \cdot 5\end{array}$ & $\begin{array}{r}55 \\
386 \\
900\end{array}$ & $\begin{array}{l}2100 \\
3951 \\
5950\end{array}$ & $\begin{array}{r}12 \\
124 \\
275\end{array}$ & $\begin{array}{r}3 \\
29 \\
100\end{array}$ & $\begin{array}{r}850 \\
1628 \\
2500\end{array}$ & $\begin{array}{r}75 \\
440 \\
750\end{array}$ & $\begin{array}{l}-201 \\
-88 \\
+702\end{array}$ & 668 \\
\hline
\end{tabular}

Table III Hemalog-D cytochemical automated counts giving percentile estimates of differential white cell counts in normal individuals

\section{Discussion}

The cytochemical principle of the Hemalog-D $\mathrm{D}^{\mathrm{TM}}$ attempts to mark uniquely a cell with dye and count these cells suspended in a liquid vehicle. As they pass through a photometric counting device the measured amount of light removed from an illuminating beam by a dyed cell is compared to that removed by an undyed cell. Quantitative variations in the dye content of the cell can be detected by threshold detectors and thus afford identification of heavily dyed, moderately dyed, and undyed cells. The cell size, as it passes the detector, is calculated by virtue of its light-scattering effect and is simultaneously measured.

The enzymatic chemistry of the Hemalog-DTM has been the subject of papers by Ansley and Ornstein (1970) and Davidson (1970). Neutrophils and eosinophils are stained at a pH of between 3.0 and 5.0 for peroxidase activity. At this high $\mathrm{pH}$, the eosinophil granules are stained heavily, and the neutrophil granules only moderately. All other cells remain essentially negative.

Schmalzl and Braunsteiner (1968) have called attention to a strong esterase activity in monocytes and moderate activity of this enzyme in neutrophils near pH 7.0. By modifying their technique using a $\mathrm{pH}$ of 6.0 (Ansley and Orstein, 1970), it is possible to detect strong lipase activity only in monocytes. Heparin accumulation in the basophil granules is estimated by staining with toluidine blue, and lymphocytes are counted by a combination of their lack of measurable enzyme activity in the apparatus and by their size (light scattering ability).

The cell types calculated by the Hemalog- $\mathrm{D}^{\mathrm{TM}}$ differ from those produced by manual differential white cell counts in two main classifications, namely, bands and immature cells.

Band cells have been traditionally classified on the appearance of the nuclear staining and chromatin thickness dividing the two nuclear lobes. This arbitrary distinction that separates cell age has been the subject of much disagreement and confusion in the past and has often resulted in a subjective decision highly influenced by the observers' training. The Hemalog-D $\mathrm{D}^{\mathrm{TM}}$ classifies manual bands as 'juveniles'. This classification is both misleading and probably inaccurate. The term 'juvenile' has traditionally been used to describe a granulocyte having a more immature morphological appearance than a band, but being more mature than a myelocyte, ie, metamyelocyte. It is at present, unclear, if the Hemalog-DTM 'juvenile' encompasses both the manual band and all or part of the manual juvenile group of cells. It is reasonable to speculate that the enzyme activity and size of a cell may not agree with its morphological visual appearance, and thus the difference in normal ranges reported should not necessarily be cause for concern. It is possible that the cytochemical differentiation may be closer to the 'true' result than manual observation, and may represent a correlation with clinical findings more closely than previously used criteria. Such postulations, however, have to be further explored with clinical data and cannot be substantiated from the data presented. Little significance can be attributed to the differences in normal ranges reported between the two methods in the other usually seen cell types. Clinical importance relies primarily on the comparison of data with a 'normal' population tested by the same method and not upon raw results. Thus test results determined by different methods can only be compared when each result is reviewed against its own set of normals.

One exception to these comments is in the production of results not normally encountered by conventional methods. The counting of 'unclassified' cells by the Hemalog- $\mathrm{D}^{\mathrm{T} M}$ produced data difficult to analyse. Cells placed in this group are not necessarily unclassified by standard morphological 
criteria. A positive 'unclassified' result is believed to represent cells having a reduction in cytochemical staining properties (reduced peroxidase activity in neutrophils and eosinophils, reduced lipase activity in monocytes, immature cells, atypical cells), and a negative 'unclassified' figure is believed associated with cells being counted in two or three channels of the system. Such cells are thought to exhibit multiple staining enzyme characteristics such as both lipase and peroxidase activity. They are then recorded in both monocyte and neutrophil groups. If cells possess poor staining qualities, the total number of cells counted by the apparatus will not agree with the sum of the totals in all channels, and the apparatus computes a positive figure in the unclassified compartment. Likewise, if the cells are counted in more than one group, the percentage is adjusted by means of a negative unclassified group. Two normal individuals having 'poorly staining' cells were further examined by viewing the effluent of the blood stain mixture designed from the $\mathrm{H}$ emalog$\mathrm{D}^{\mathrm{TM}}$. In both cases the monocytes appeared to be low in lipase activity. Both of these donors were in excellent health. Lipase activity was then estimated by a manual modification of the automated procedure (Ansley and Ornstein, 1970) and similar results were again found.

Despite these findings it is questionable that the narrower limits of the Hemalog- $\mathrm{D}^{\mathrm{TM}}$ have any statistical significance since up to $10 \%$ of the cells were 'unclassified' by the Hemalog- $\mathrm{D}^{\mathrm{TM}}$ while more were placed in the immature group by the manual method. Apportioning these $10 \%$ to lymphocytes and segmented neutrophils would very likely result in figures even more closely duplicating the visual counts. The clinical significance, if any, of the Hemalog- $\mathrm{D}^{\text {TM }}$ unclassified group is, thus, unknown. Its further investigation could be useful in the complete understanding of the physiology and chemistry of leucocytes.

The remainder of the comparative results were strikingly similar. The expected closer normal ranges were found in the Hemalog- $\mathrm{D}^{\mathrm{TM}}$ results and primarily reflect the number of cells counted, as 100 cell counts were being compared with 10000 cell counts. No clinically significance differences were observed in either sex or related /to patient age in any cells of the manual differential count, with the exception of the 10-19 age group. Little difference was observed between sexes in the Hemalog- $D^{\text {TM }}$ method. The 126 samples tested in 10-19 age group showed slightly higher lymphocyte levels compared with the overall population and this can be attributed to a mild lymphocytosis associated with the younger members of this group.

Despite previously published data, it was surprising to find the wide limits found in both neutrophils $(42-81 \%)$ and lymphocytes $(10-47 \%)$ by manual methods, and by Hemalog-D ${ }^{\mathrm{TM}} \quad(47 \cdot 56-74 \cdot 57 \%$ neutrophils, $15 \cdot 86-38 \cdot 55 \%$ lymphocytes). These results are also reflected in the range calculated for absolute numbers of cells.

\section{Conclusion}

It is difficult to compare adequately the classification of cells by dissimilar methods. The well tried and familiar morphological criteria used by all laboratories may not necessarily reflect accurate pathological changes in the activity of the cell. The 'normal' ranges as determined by this laboratory for both manual and cytochemically automated procedures have shown some similarity, but expected discrepancies did occur. More extensive investigations using the Hemalog-DTM on the 'unclassified' cells has to be undertaken before a true explanation of this phenomenon is propounded.

We are grateful to the Technicon Corporation for the use of the preproduction model of the Hemalog$\mathrm{D}^{\mathrm{TM}}$.

\section{References}

Ansley, H., and Ornstein, L. (1970). Enzyme histochemistry and differential white cell counts on the Technicon Hemalog D In Advances in Automated Analysis, Vol. 1, pp. 437-446. Thurman Associates, Miami.

Davidson, E. (1970). Consecutive cytochemical staining. In Advances in Automated Analysis, Vol. 1, pp. 447-451. Thurman Associates Miami.

Fowler, W. M. (1945). Hematology, p. 60. Hoeber, New York.

Miale, J. B. (1972). Laboratory Medicine:Hematology, 4th ed., p. 906. Mosby, St. Louis.

Orfanakis, N. G., Ostlund, R. E., Bishop, C. R., and Athens, J. W. (1970). Normal blood leukocyte concentration values. Amer. J. clin. Path., 53, 647-651.

Osgood, E. E., Brownlee, I. E., Osgood, M. W., Ellis, D. M., and Cohen, W. (1939). Total, differential and absolute leukocyte counts and sedimentation rates determined for healthy persons nineteen years of age and over. Arch. intern. Med., 64, 105-120.

Sandoz, Ltd.(1952). Atlas of Haematoiogy, p. 38. Sandoz Ltd, Basle.

Schmalzl, F., and Braunsteiner, H. (1968). On the origin of monocytes. Acta haemat., 39, 177-182.

Sturgis, C. C., and Bethell, F. H. (1943). Quantitative and qualitative variations in normal leukocytes. Physiol. Rev., 23, 279-284.

Whitby, L. E. H., and Britton, C. J. C. (1963). In Disorders of the Blood, 9th ed., edited by C. J. C. Britton, p. 15. Churchill, London.

Wintrobe, M. M. (1967). Clinical Hematology, 6th ed., p. 260. Lea and Febriger, Philadelphia Kimpton, London.

Zacharski, L. R., Elveback, L. R., and Linman, J. W. (1971). Leukocyte counts in healthy adults. Amer. J. clin. Path., 56, 148-150. 